\title{
NOTE
}

\section{Ingestion of a bacterivorous ciliate by the oyster Crassostrea gigas: protozoa as a trophic link between picoplankton and benthic suspension-feeders}

\author{
Solange Le Gall ${ }^{1, *}$, Malika Bel Hassen ${ }^{1}$, Pierre Le Gall ${ }^{2}$ \\ ${ }^{1}$ CNRS/IFREMER, CREMA BP 5, F-17137 L'Houmeau, France \\ ${ }^{2}$ LBBM, Université de La Rochelle, F-17042 La Rochelle, France
}

\begin{abstract}
The linked concepts of 'microbial loop' and 'protozoan trophic link' have been very well documented in filter-feeding microzooplankton such as copepods, but have not been applied to energy transfer to benthic suspensionfeeding macrofauna, with the exception of the recent demonstration of heterotrophic flagellate assimilation by mussels. The oyster Crassostrea gigas obtains energy resources by filtering microalgae $(-5$ to $100 \mu \mathrm{m})$. However, in turbid estuaries, light-limited phytoplanktonic production cannot entirely account for oyster energy requirements. Conversely, picoplankters $(<2 \mu \mathrm{m})$, which are main effectors of coastal energy flow and matter cycling, are not efficiently retained by oyster filtration. Ciliate protozoa, as both micro-sized cells $(\sim 5$ to $100 \mu \mathrm{m})$ and bacteria grazers, may represent a major intermediary in trophic transfer between picoplankton and metazoa. The ciliate Uronema was intensely cultured and labelled, using the cyanobacteria Synechococcus as an autofluorescent biomarker. The labelled ciliates were offered as potential prey to oysters. We report here the first experimental evidence of a significant retention and ingestion of ciliates by oysters, supporting the role of protozoa as a realistic trophic link between picoplankters and filter-feeding bivalves and thus enhancing their potential importance in estuarine microbial food webs.
\end{abstract}

KEY WORDS: Oyster - Food sources - Picoplankton Protozoa Trophic link

Oysters obtain energy resources by filtering particles from sea water, and their growth and fecundity depends upon the nutritive value of the retained seston (Berg \& Newell 1986). In turbid estuaries such as the oyster-rearing Marennes-Oléron Bay (France), the light-limited amounts of phytoplankton cannot entirely account for the energy requirements of the benthic suspension-feeding oyster Crassostrea gigas (Héral 1987).

•E-mail: slegall@ifremer.fr
Conversely, microbial consortia play a key role in marine food webs (Pomeroy 1974). In coastal ecosystems, heterotrophic bacterioplankters significantly contribute to the microbial biomass (Fuhrman \& Azam 1980 ) and up to 50 to $60 \%$ of total carbon flow passes through bacterioplankters (Newell \& Linley 1984). An important part of production and respiration in marine ecosystems is processed through picoplankters less than $2 \mu \mathrm{m}$ in size, such as heterotrophic bacteria (Ferguson \& Rublee 1976, Fuhrman 1992), autotrophic cyanobacteria (Johnson \& Sieburth 1979, Waterbury et al. 1979, Glover et al. 1986) and small eukaryotic phototrophic plankters (Johnson \& Sieburth 1982, Courties 1994). With rapid growth rates and high growth efficiencies, heterotrophic bacterioplankters constitute a significant pathway of $\mathrm{C} / \mathrm{N}$ flow by recycling dissolved organic matter (DOM) into particles potentially available to upper trophic levels (Pomeroy 1974, Williams 1981, Azam et al. 1983, Sherr \& Sherr 1988).

However, micrometre-sized bacteria or cyanobacteria are not efficiently retained by bivalve filtration, particularly not by oysters (Shumway et al. 1985, Héral 1987, Riisgård 1988, Barillé et al. 1993). Ciliate protozoa, as both bacteria grazers (Hamilton \& Preslan 1969, Berk et al. 1976, Sherr \& Sherr 1987, Kemp 1988, Bernard \& Rassoulzadegan 1990, Caron et al. 1991) and copepod prey (Berk et al. 1977, Sheldon et al. 1986), have been suggested as a major trophic link between bacteria and micro- or macrozooplankton (Porter et al. 1979, Sherr et al. 1986b, Sime-Ngando et al. 1995).

In the same way, do picoplankters unretained by filter-feeding bivalves contribute indirectly to their diet via ingestion of protists supplementing the phytoplankton (Fig 1)? Some data support this assumption: 


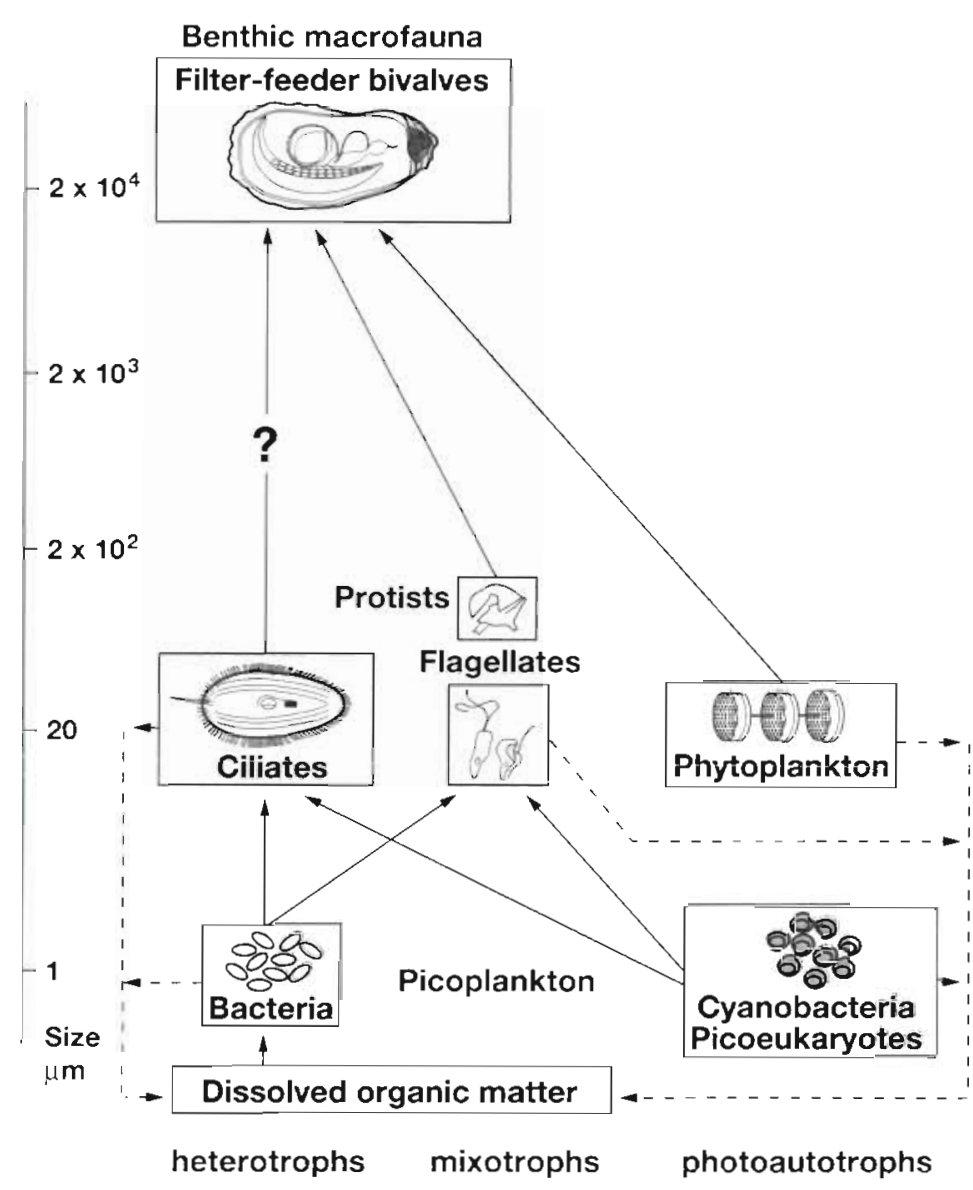

Fig. 1. Hypothetical diagram of microbial food webs in a coastal shellfish ecosystem

presence of tintinnids was observed in the stomach contents of oysters (Paulmier 1972) and mussels added into experimental marine enclosures reduced by more than $50 \%$ the biomass of microzooplankton, mainly tintinnids and oligotrich ciliates (Riemann et al. 1990). Moreover, protists are retained by filter-feeding mollusks, as examplified by contaminations of bivalves by toxic flagellates (Sournia et al. 1991). In a mixed cell suspension of phytoplankton and dinoflagellates, 6 different species of bivalves were able to clear selectively and digest the dinoflagellates (Shumway et al. 1985). Recently, ingestion and assimilation of bacterial carbon via heterotrophic flagellates was clearly demonstrated in mussels (Kreeger \& Newell 1996).

Experimental evidence of oysters grazing on ciliate protozoa is presented here via a model system simulating a simplified food web: bacteria $\Rightarrow$ ciliate $\Rightarrow$ oyster, using Uronema, a bacterivorous ciljate, in the size range of phytoplanktonic cells that oysters usually feed. upon.

Methods and results. Intensive culture of the bacterivorous ciliate Uronema: Uronema were caught in the field and cultured (Hamilton \& Preslan 1969) for
48 h on suspension of natural bacterial consortia at a concentration of $1 \times 10^{6}$ bacteria $\mathrm{ml}^{-1}$. Ciliate abundances were estimated from alkaline lugol-fixed samples (Sherr et al. 1989) in Nageotte counting cells or Utermöhl settling columns, according to the expected concentration. The cultured ciliates in early stationary phase $\left(90 \times 10^{3}\right.$ cells $\left.\mathrm{ml}^{-1}\right)$ were separated from their bacterial prey by differential centrifugation (Ohman \& Snyder 1991), washed twice in phosphate buffer saline (PBS) and resuspended in autoclaved $0.2 \mu \mathrm{m}$ filtered sea water (FSW) at experimental concentrations of $5 \times 10^{3}$ cells $\mathrm{ml}^{-1}$ and $8.8 \times 10^{3}$ cells I $^{-1}$. Collected cells were mobile and able to develop intensely in culture. Carbon and nitrogen analysis of Uronema was performed on an ERBA elemental auto analyser. The determined $C: N$ ratio was $6.2 \pm$ $0.5(n=3)$, a value closely related to $C: N$ estimates in phytoplanktonic cells

Grazing of Crassostrea gigas on ciliates: The Uronema were offered as potential prey to oysters at a concentration regulated in the range of the natural abundance of ciliates: at the time of the experiment, $12 \times 10^{3}$ ciliates $1^{-1}$ were enumerated in the oyster pond. One year old Crassostrea gigas $(5 \mathrm{~cm}$ long and $1 \mathrm{~g}$ dry weight flesh) were kept overnight in FSW. The possible influence of oyster filtration was studied by comparing the evolution of ciliate abundances in triplicate $400 \mathrm{ml}$ suspensions, with or without an oyster. In 3 isolated ciliate suspensions, gently homogenized to prevent sedimentation, the abundance of Uronema $\left(8.8 \times 10^{3}\right.$ cells $\left.1^{-1}\right)$ remained relatively constant for $20 \mathrm{~min}$ (Fig. 2). The introduction of Uronema in 3 experimental oyster trays induced the set-up of an active pumping behaviour of the mollusks. The oyster filtration triggered in ciliate suspensions an $88 \%$ decrease in Uronema abundance within 20 min (Fig. 2).

Moreover, careful withdrawal of seawater aliquots from the oysters' exhalant siphons with a bent Pasteur pipet (Le Gall \& Béchemin 1994) allowed a comparison between the protozoan concentrations in the inhalant versus exhalant siphon: after a single passage through the oyster gills, the decrease in Uronema abundance

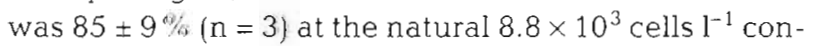
centration. In a more concentrated suspension $(5 \times$ $10^{3}$ cells $\left.\mathrm{ml}^{-1}\right)$, only $44 \pm 13 \%(n=5)$ of Uronema were retained on the gills: unnaturally high concentration of particulate food is likely to restrict retention efficiency in oysters (Barillé et al. 1993). Even in the range of natural ciliate abundances, the retention of Uronema $(85 \%)$ is lower than the retention of algal particles 


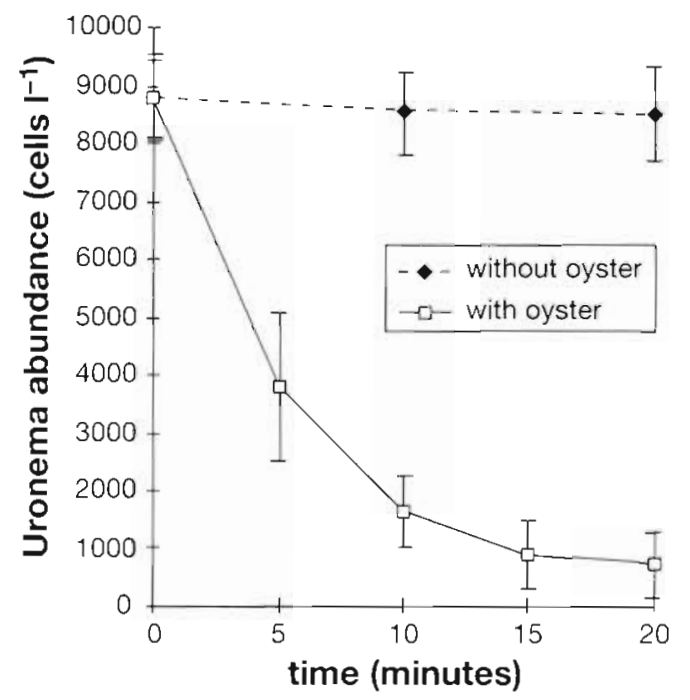

Fig. 2. Retention of Uronema by oyster Crassostrea gigas. Data were collected from 6 separate experiments performed in $400 \mathrm{ml}$ ciliate suspensions without an oyster ( $)$ or with an oyster ( $\square$ ). Ciliate abundances (mean \pm SD) were estimated from alkaline lugol-fixed samples

( $100 \%$ for microalgae $>5 \mu \mathrm{m}$ ) (Shumway et al. 1985 , Riisgård 1988): the active swimming behaviour of Uronema might allow some of them to escape the strong inhalant current of the bivalve.

Ingestion of the ciliates by Crassostrea gigas: The disappearance of Uronema during the passage of the suspension through the branchial chamber might have resulted from the destruction of those fragile organisms upon contact with the mollusk filtration apparatus. The fate of the ciliates in the Crassostrea gigas gut was studied through fluorescent labelling, using autofluorescent cyanobacterial prey as the biotracer for ciliates.

Uronema which had been starved overnight were fed a Synechococcus ROSO4 culture at a natural $(6 \times$ $10^{5}$ cells $\mathrm{ml}^{-1}$ ) concentration (Glover et al. 1986). Cyanobacteria had been sonicated ( $75 \mathrm{~W}, 2 \mathrm{~min}$ ) to avoid cell clumping. Two hours later, ciliates observed by epifluorescence microscopy under blue light excitation appeared intensely labelled by their yellow-gold autofluorescent cyanobacterial prey, which had been both caught on cilia and ingested in the internal vacuoles of the protozoa (Fig. 3A).

Oysters were offered 3 different experimental suspensions: (1) FSW without any particles, (2) Synechococcus suspensions $\left(6 \times 10^{5}\right.$ cells $\left.\mathrm{ml}^{-1}\right)$ or (3) Uronema suspensions $\left(5 \times 10^{3}\right.$ cells $\left.\mathrm{m}^{-1}\right)$ labelled with previously ingested Synechococcus. Non-filtrating oysters were discarded. Stomach and intestine contents of oysters were dissected 30 min later, gently pipetted, filtered on black $0.2 \mu \mathrm{m}$ Nuclepore and observed by epifluorescence microscopy to detect the labelled ciliates possibly ingested by the mollusk.
In 3 oysters filtering FSW, the stomachs and intestines were flat and empty, as could easily have been predicted (Fig. 3B). The 3 filtrating oysters offered the Synechococcus suspensions also had flat guts. Epifluorescent examination of filtered stomach contents revealed phytoplanktonic residues, characterized by chlorophyll red autofluorescence and rare cyanobacterial cells (Fig. 3C). Conversely, oysters offered the biolabelled Uronema suspensions exhibited expanded guts filled with a pinkish material. Epifluorescent examination revealed large amounts of autofluorescent cyanobacteria clumped on residual membranes of labelled ciliates in the stomach (Fig. 3D) and intestine (Fig. 3E) contents of oysters.

Discussion. The oyster Crassostrea gigas intensely retains and ingests the $20 \mu \mathrm{m}$ bacterivorous ciliate prey: at a concentration close to natural abundances of ciliates in the field, about $85 \%$ of the suspended Uronema were retained on the oyster gills. The C:N value in Uronema $(\sim 6)$, similar to the ratio usually found in phytoplankton, makes them potentially valuable food sources. Moreover, picocyanobacterial cells at a natural concentration, which were inefficiently filtered by oysters, were indirectly ingested via our experimental protozoan trophic link. Questions always remain concerning the extrapolation to nature of in vitro data: the ciliate Uronema we used here may not realistically represent the natural planktonic consortium, but it can be considered as a model for picoplanktivorous protozoa, sized in a range of oyster retention.

Oysters have been shown to preferentially ingest organic particles (Newell \& Jordan 1983). They are able to selectively clear dinoflagellate protists from diatom/dinoflagellate mixtures (Shumway et al. 1985), although toxic species reduce molluskan filtration (Newell \& Shumway 1993) and feeding (Bardouil et al. 1996). Moreover, heterotrophic flagellates contribute to the $C$ requirements of 2 mussel species, with assimilation efficiencies in the same range as for phytoplankton (Kreeger \& Newell 1996). Tintinnid protozoa were observed to be abundant in the stomachs of wild oysters (Paulmier 1972). Such ability of oysters to ingest and assimilate protozoan cells as well as phytoplankton supports the idea that they have wide trophic adaptability (Kreeger \& Newell 1996, Riera \& Richard 1996).

Picoplankters may be responsible for 25 to $80 \%$ of the primary production in marine coastal ecosystems and are main effectors of energy flow and nutrient cycling. In Atlantic oyster ponds, bacteria contribute up to $56 \%$ of the particulate organic $\mathrm{C}$ biomass (Frikha et al. 1987). In the marine Thau lagoon, a major shellfish coastal zone in France, the photosynthetic picoeukaryote Ostreococcus tauri is the main component of the phytoplankton (Courties et al. 1994). Similarly, cyanobacteria and picoeukaryotes represent more 


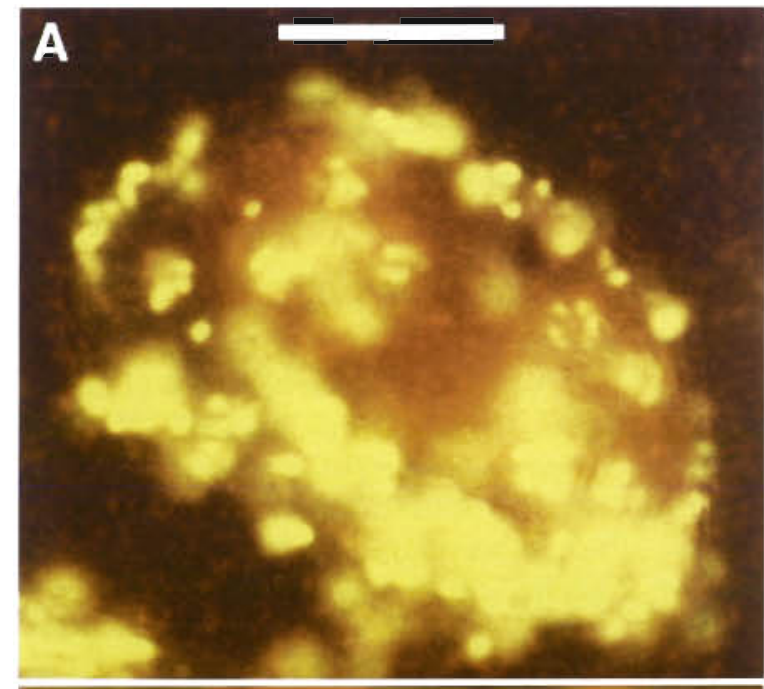

Fig. 3. Ingestion of cliates by oyster Crassostrea gigas Ciliate 'biolabelling' was performed by feeding starved Uronema on a $6 \times 10^{5}$ cells $\mathrm{ml}^{-1}$ Synechococcus suspension. The yellow-gold autofluorescence of the biomarker Synechococcus was revealed by epifluorescence microscopy under blue-light excitation. (A) Uronema fed on a $6 \times 10^{5}$ cells ml-1 Synechococcus suspension and intensely 'biolabelled' by its cyanobacterial prey. (B) Stomach content of an oyster filtrating FSW. (C) Stomach content of an oyster filtrating a free Synechococcus suspension $\left(6 \times 10^{5}\right.$ cells ml $\left.{ }^{-1}\right)$. (D, E) Synechococcus-labelled Uronema residues in the stomach (D) and intestine (E) of an oyster filtrating a suspension of previously biolabelled ciliates. Scale bar $=10 \mu \mathrm{m}$
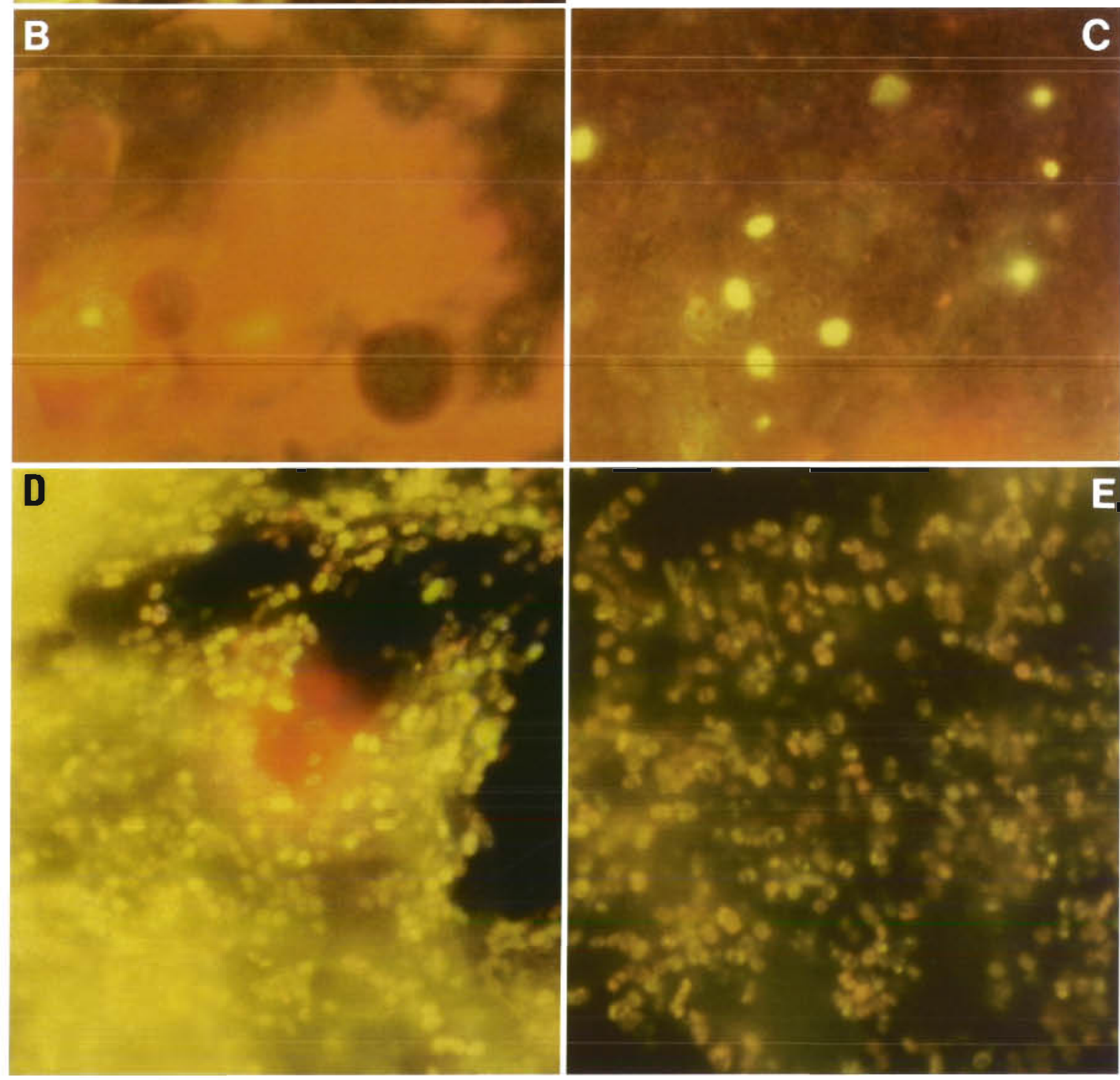
than $60 \%$ of phytoplanktonic biomass and production in the pearl oyster culture grounds of the Polynesian lagoons (Charpy \& Blanchot 1996). Bacteria are considered as a major food resource in marine Atlantic ponds (Linley 1986) and in coral reef lagoons (Linley \& Koop 1986). These tiny cells are absorbed by deposit-feeding bivalves (Newell \& Shumway 1993) and some mussels (Kreeger \& Newell 1996), but they are not efficiently retained by most filter-feeders, particularly oysters (Shumway et al. 1985, Riisgård 1988). Conversely, the bulk of bacterial production is rapidly consumed by protozoa (Frikha \& Linley 1989, Van Wambeke et al 1996), these constituting a potential trophic link between picoprey and oysters.

The transfer of the picoplanktonic biomass through the heterotrophic food webs and the significance of its link or sink value (Pomeroy 1974, Ducklow et al. 1986, Sherr et al. 1987) is still a controversial issue. Moreover, direct use of primary decomposers (bacteria) rather than protozoa would allow conservation of more energy for macrometazoa, because of losses occurring along the food chain (Linley \& Newell 1981). However, in coastal waters, such as nutrient-rich estuaries, ciliate protozoa with abundances of $10^{3}$ to $10^{5}$ cells $l^{-1}$ are a major component of zooplankton (Sherr et al. 1986a). They are considered efficient grazers of bacteria and cyanobacteria, at least temporally and locally (Rassoulzadegan 1993). Our experimental evidence of an important retention and ingestion of a ciliate by Crassostrea gigas is consistent with the observation of ciliates in the stomach contents of wild oysters (Paulmier 1972). Protozoa may thus represent a realistic trophic link through which DOM and picoplankters contribute to the food resources of large benthic metazoan suspension feeders, such as oysters.

Acknowledgements. We thank Martine Bréret (CNRS) for technical assistance in cyanobacteria and ciliate culture, Lucette Joassard (IFREMER) for $\mathrm{C}$ and $\mathrm{N}$ analysis and Daniel Vaulot (Roscoff) for the gift of the Synechococcus ROSO4 cell line.

\section{LITERATURE CITED}

Azam F, Fenchel T, Field JS, Meyer-Reil LA, Thingstad F (1983) The ecological role of water-column microbes in the sea. Mar Ecol Prog Ser 10:257-263

Bardouil M, Bohec M, Bougrier S, Lassus P, Truquet P (1996) Feeding responses of Crassostrea gigas (Thunberg) to inclusion of different proportions of toxic dinoflagellates in their diet. Oceanol Acta 19:177-182

Barillé L, Prou J, Héral M, Bougrier S (1993) No influence of food quality, but ration-dependent retention efficiencies in the Japanese oyster Crassostrea gigas. J Exp Mar Biol Ecol 171:91-106

Berg JA, Newell RIE (1986) Temporal and spatial variations in the composition of seston available to the suspension feeder Crassostrea virginica. Estuar Coast Shelf Sci 23 375-386

Berk SG, Brownlee DC, Heinle DR, Kling HJ, Colwell RR (1977) Ciliates as a food source for marine planktonic copepods. Microbiol Ecol 4:27-40

Berk SG, Colwell RR, Small EB (1976) A study of feeding responses to bacterial prey by estuarine ciliates. Trans Am Microsc Soc 95:514-520

Bernard C, Rassoulzadegan F (1990) Bacteria or microflagellates as a major food source for marine ciliates: possible implications for the microzooplankton. Mar Ecol Prog Ser 64:147-155

Caron DA, Lim EL, Miceli G, Waterbury JB, Valois FW (1991) Grazing and utilization of chroococcoid cyanobacteria and heterotrophic bacteria by protozoa in laboratory cultures and a coastal plankton community. Mar Ecol Prog Ser 76: 205-217

Charpy L, Blanchot J (1996) Prochlorococcus contribution to phytoplankton biomass and production of Takapoto atoll (Tuamotu archipelago). C R Acad Sci Paris Sci Vie 319: $131-137$

Courties C, Vaquer A, Trousselier M, Lautier J, ChrétiennotDinet MJ, Neveux J, Machado C, Claustre H (1994) Smallest eukaryotic organism. Nature Lond 370:255

Ducklow HW, Purdie DA, Williams PJLeB, Davies JM (1986) Bacterioplankton: a sink for carbon in a coastal manine plankton community. Science 232:865-867

Fergusson RL, Rublee P (1976) Contribution of bacteria to standing crop of coastal plankton. Limnol Oceanogr 21 $141-144$

Frikha MG, Linley EAS (1989) Predation on bacterioplankton in oyster ponds of the Atlantic coast of France. Mar Microb Food Webs 3:67-78

Frikha MG, Linley EAS, Delmas D (1987) Evolution annuelle et saisonnière de la microbiomasse d'une claire à huîtres: importance des populations bactérioplanctoniques. Oceanis 13:433-447

Fuhrman J (1992) Bacterioplankton roles in cycling of organic matter: the microbial food web. In: Falkowski PG, Woodhead AD (eds) Primary productivity and biogeochemical cycles in the sea. Plenum Press, New York, p 361-383

Fuhrman JA, Azam F (1980) Bacterioplankton secondary production estimates for coastal waters of British Columbia, Antarctica and California. Appl Environ Microbiol 39: $1085-1095$

Glover HE, Phinney DA, Yentsch CS (1986) Photosynthetic characteristics of picoplankton compared with those of larger phytoplankton populations in various water masses in the gulf of Maine. Biol Oceanogr 3:223-248

Hamilton RD, Preslan JE (1969) Cultural characteristics of a pelagic marine hymenostome ciliate Uronema sp. J Exp Mar Biol Ecol 4:90-99

Héral M (1987) Evaluation of the carrying capacity of molluskan shellfish ecosystems. In: IFREMER (ed) Shellfish culture development and management. International seminar in La Rochelle (France), 4-9 March 1985. IFREMER, SDP, Brest, p 287-317

Johnson PW, Sieburth JMcN (1979) Chroococcoid cyanobacteria: a significant component in the sea and an ubiquitous and diverse photobiomass. Limnol Oceanogr 24:928-935

Johnson PW, Sieburth JMcN (1982) In situ morphology and occurrence of eukaryotic phototrophs of bacterial size in the picoplankton of estuarine and oceanic waters. J Phycol 18:318-327

Kemp PF (1988) Bacterivory by benthic ciliates: significance as a carbon source and impact on sediment bacteria. Mar Ecol Prog Ser 49:163-169 
Kreeger DA, Newell RIE (1996) Ingestion and assimilation of carbon from cellulolytic bactena and heterotrophic flagellates by the mussels Geukensia demissa and Mytilus edulis (Bivalvia, Mollusca). Aquat Microb Ecol 11:205-214

Le Gall S, Bechemin C (1994) Incidence écophysiologique de I'absorption épithéliale d'acides aminés dissous par Crassostrea gigas. C R Acad Sci Paris Sci Vie 317:457-460

Linley EAS (1986) Les bactéries des marais endigués: des picoproies de grande richesse? Ann Soc Sci Nat CharenteMar 7:481-483

Linley EAS, Koop K (1986) Significance of pelagic bacteria as a trophic resource in a coral reef lagoon, One Tree Island, Great Barner Reef. Mar Biol 92:457-464

Linley EAS, Newell RC (1981) Microheterotrophic communities associated with the degradation of kelp debris. Kieler Meeresforsch 5:345-355

Newell CR, Shumway SE (1993) Grazing of natural particulates by bivalve moliusks: a spatial and temporal perspective. In: Dame RF (ed) Bivalve filter feeders in estuarine and coastal ecosystem processes. Springer-Verlag, Berlin, p $85-148$

Newell RC, Linley EAS (1984) Significance of microheterotrophs in the decomposition of phytoplankton: estimates of carbon and nitrogen flow based on the biomass of plankton communities. Mar Ecol Prog Ser 16:105-119

Newell RIE, Jordan SJ (1983) Preferential ingestion of organic material by the american oyster Crassostrea virginica. Mar Ecol Prog Ser 13:47-53

Ohman MD, Snyder RA (1.991) Growth kinetics of the omnivorous oligotrich ciliate Strombidium sp. Limnol Oceanogr $36(5): 922-935$

Paulmier G (1972) La nutrition des huîtres en relation avec les sources trophiques. Rev Trav Inst Pêches Marit 36(4) $456-506$

Pomeroy LR (1974) The ocean's food web: a changing paradigm. BioSci 24:499-504

Porter KG, Pace ML, Battey JF (1979) Ciliated protozoans as links in freshwater planktonic food chains. Nature Lond 277:563-565

Rassoulzadegan F (1993) Protozoan patterns in the AzamAmmerman's bacteria-phytopankton mutualism. In: Guerrero R, Pedros-Alio C (eds) Trends in microbial ecology. Proceedings of the sixth international symposium on microbial ecology, Barcelona, 6-11 September 1992. Spanish Society for Microbiology, Barcelona, p 435-439

Riemann B, Sorensen HM, Bjornsen PK, Horsted SJ, Jensen LM, Nielsen TG, Sondergaard M (1990) Carbon budgets of the microbial food wed in estuarine enclosures. Mar Ecol Prog Ser 65:159-170

This note was submitted to the editor
Riera P, Richard P (1996) Isotopic determination of food sources of Crassostrea gigas along a trophic gradient in the estuarine bay of Marennes-Oléron. Estuar Coast Mar Sci $42: 347-360$

Riisgård HU (1988) Efficlency of particle retention and filtration rate in 6 species of North east American bivalves. Mar Ecol Prog Ser 45:217-223

Sheldon RW, Nival P, Rassoulzadegan F (1986) An experimental investigation of a flagellate-ciliate-copepod food chain with some observations relevant to the linear biomass hypothesis. Limnol Oceanogr 31:184-188

Sherr BF, Sherr E, Pedros-Alio C (1989) Simultaneous measurement of bacterioplankton production and protozoan bacterivory in estuarine water Mar Ecol Prog Ser 54: 200-219

Sherr EB, Sherr BF (1987) High rates of consumption of bacteria by pelagic ciliates. Nature Lond 325:710-711

Sherr EB, Sherr BF (1988) Role of microbes in pelagic food webs: a revised concept. Limnol Oceanogr 33:1225-1227

Sherr EB, Sherr BF, Albright LJ (1987) Bacteria: Link or sink? Science 235:88-89

Sherr EB, Sherr BF, Fallon RD, Newell SY (1986a) Small aloricate ciliates as a major component of the marine hoterotrophic nanoplankton. Limnol Oceanogr 31:177-183

Sherr EB, Sherr BF, Paffenhöfer GA (1986b) Phagotrophic protozoa as food for metazoans: a 'missing' trophic link in marine pelagic food webs? Mar Microb Food Webs 1:61-80

Shumway SE, Cucci TL, Newell RC, Yentsch CM (1985) Particle selection, ingestion and absorption in filter-feeding bivalves. J Exp Mar Biol Ecol 91:77-92

Sime-Ngando T, Gosselin M, Roy S, Chanut JP (1995) Signifjcance of planktonic ciliated protozoa in the Lower St. Lawrence Estuary: comparison with bacterial, phytoplankton, and particulate organic carbon. Aquat Microb Ecol 9:243-258

Sournia A, Belin C, Berland B, Erard-Le Denn, Gentien P. Grzebyk D, Marcaillou-Le Baut C, Lassus P, Partensky F (1991) Le phytoplancton nuisible des côtes de France. De la biologie à la prévention. IFREMER-CNRS, Brest

Van Wambeke F, Christaki U, Gaudy R (1996) Carbon fluxes from the microbial food web to mesozooplankton. An approach in the surface layer of a pelagic area (NW Mediterranean sea). Oceanol Acta 19:57-66

Waterbury JB, Watson SW, Guillard RRL, Brand LE (1979) Widespread occurrence of a unicellular, marine, planktonic cyanobacterium. Nature Lond 277:293-294

Williams PJleB (1981) Incorporation of microheterotrophic processes into the classical paradigm of the planktonic food web. Kieler Meeresforsch 5:1-28

Manuscript first received: December 2, 1996

Revised version accepted: April 7, 1997 